\title{
Lumbung Padi Indonesia dan Kemiskinan: Studi Kasus Kabupaten Kota di Jawa Timur
}

\author{
Diana Rizky Safitri ${ }^{1 *}$, Estro Dariatno Sihaloho ${ }^{2}$ \\ 1,2 Departemen Ilmu Ekonomi Fakultas Ekonomi dan Bisnis Universitas Padjadjaran \\ Jln. Dipati Ukur No. 35, Bandung, 40132, Jawa Barat, Indonesia \\ *correspondence email: diana16003@ mail.unpad.ac.id
}

\begin{abstract}
This research aims to determine whether the area called as a rice barn in Indonesia can alleviate the poverty problem in the region. East Java is Indonesia's rice barn with a total production of $16.1 \%$ of the total rice production in Indonesia. This research uses panel data and fixed-effect methods with quantitative analysis. The data used is secondary data obtained from the website of the Ministry of Agriculture of the Republic of Indonesia (KPRI) and the Indonesian Bureau of Central Statistics (BPS) with data on city districts in 2014 - 2017. This research uses the variable percentage of poverty in the Regency of East Java City as the dependent variable, the percentage level farmer productivity, percentage of agricultural land area, and the level of community consumption in East Java as independent variables. The results of the research using panel data and the fixed-effect method show that the production variable has a negative and significant impact on the percentage of community poverty in East Java Regency.
\end{abstract}

Keywords: Consumption; East Java; Farmer; Granary; Poverty

\section{PENDAHULUAN}

Kehidupan mayoritas penduduk Indonesia ditunjang oleh sektor pertanian, khususnya subsektor tanaman pangan di Indonesia (Badan Pusat Statistik, 2014). Berdasarkan data Badan Pusat Statistik (BPS) tahun 2018, Indonesia merupakan negara penghasil beras terbesar ketiga di dunia, dengan total produksi beras sebanyak 32,42 juta ton beras dan tingkat konsumsi sebanyak 29,57 ton beras pertahun (Sawit, 2006). Hal ini turut mendukung tujuan Indonesia untuk menjadi negara lumbung padi dunia pada tahun 2045. Maka dari itu, peningkatan produksi beras menjadi prioritas utama pemerintah. Pemerintah memiliki program kedaulatan pangan sebagai salah satu prioritas yang tertuang di program Nawa Cita. Tertulis pada Nawa Cita agenda ke-7 yang menyatakan "Mewujudkan kemandirian ekonomi dengan menggerakan sektor-sektor strategis ekonomi domestik". Berdasarkan data Kementerian Pertanian tahun 2018, Indonesia diharapkan dapat menyelesaikan perasalahan pangan dengan 1). Ketahanan pangan, mencukupi pangan dari produksi dalam negeri, 2) Kebijakan pangan, dan 3) Kemampuan untuk mensejahterakan petani dan nelayan.

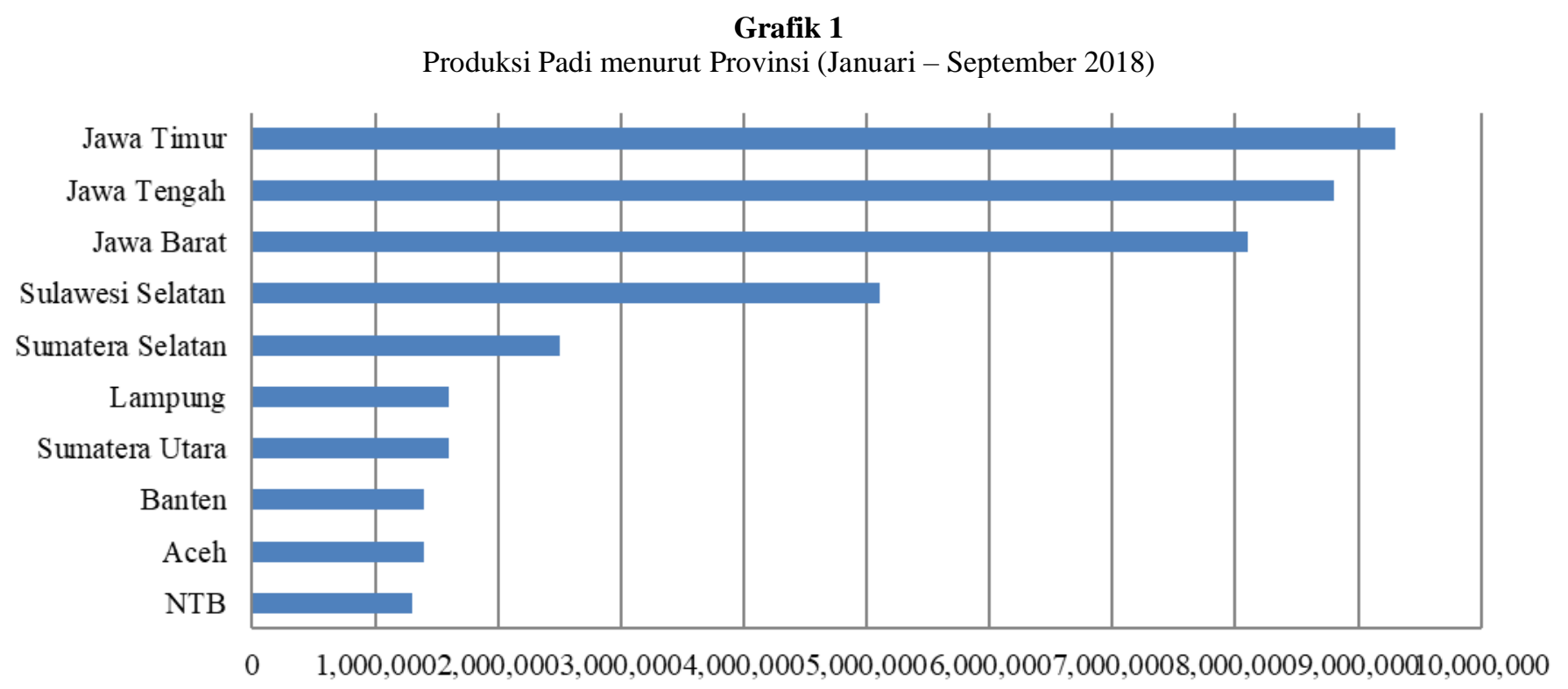

Sumber: Badan Pusat Statistik, 2019 
Jawa Timur merupakan provinsi dengan jumlah produksi beras terbanyak di Indonesia. Hal ini membuat provinsi Jawa Timur ditetapkan menjadi salah satu wilayah lumbung padi di Indonesia. Namun hal ini tidak membuat Jawa Timur terlepas dari tingkat kemiskinannya. Badan Pusat Statistik tahun 2015 menyatakan bahwa Jawa Timur merupakan provinsi dengan jumlah penduduk miskin sebanyak 3.204,82 ribu jiwa dari total penduduk sebanyak 38.847.561 ribu jiwa masyarakat yang tergolong sebagai masyarakat miskin. Masyarakat miskin didefinisikan sebagai mereka yang tergolong terbelakang dengan memiliki pengeluaran dan pendapatan di bawah rata-rata (Na'im, 1999). Permasalahan kemiskinan dapat terjadi dimanapun, baik di negara berkembang maupun maju. Baik bagi negara berkembang maupun negara maju, kemiskinan selalu menjadi salah satu permasalahan utama bagi kondisi perekonomian negara. Maka dari itu, untuk meningkatkan pembangunan negara, diperlukan solusi atas permasalahan kemiskinan. Setiap negara memiliki tolak ukur serta kebijakan dalam mengentaskan kemiskinan di negaranya.

Publikasi World Bank menjelaskan bahwa sebagai Negara berkembang, Indonesia memiliki beberapa kebijakan untuk mengentaskan kemiskinan, diantaranya adalah dengan penghapusan larangan impor beras, hal ini dikarenakan bahwa lebih dari 1,5 juta orang tergolong miskin dikarenakan kebijakan tersebut, sehingga Program Pangan Dunia (World Food Program) seharusnya diberikan izin dijalankan di Indonesia, karena dianggap sebagai kebijakan yang tepat dalam membantu petani. Kebijakan lain terkait beras adalah dengan mengganti larangan impor dengan bea masuk yang lebih rendah, serta memberikan kewenangan penetapan kebijakan bea masuk dan perdagangan lainnya hanya pada satu kementerian saja, hal ini dimaksudkan untuk menghindari konflik antar kementerian (World Bank, 2018). Kemiskinan umumnya disebabkan oleh kelaparan dan tidak tersedianya bahan pangan. Pernyataan tersebut membuat banyaknya orang yang berpendapat bahwa kemiskinan dapat diselesaikan dengan sektor pertanian. Hal ini dikarenakan pertanian, terutama penghasil beras, dianggap sebagai sumber pangan dari mayoritas masyarakat Indonesia, dimana jika ketersediaan beras dapat teratasi, permasalahan kemiskinan juga dianggap akan teratasi. Namun, ketersediaan beras dipengaruhi oleh faktor iklim, sehingga pola tanam tidak lagi dapat diprediksi seperti sebelumnya (Rum \& Sihaloho, 2017).

Padi dan beras merupakan komoditas penting di Indonesia, hal ini dikarenakan makanan pokok mayoritas orang Indonesia sendiri merupakan nasi yang dioleh dari beras dan padi. Pentingnya padi itu sendiri dapat terlihat dari adanya Undang Undang (UU) Republik Indonesia yang secara khusus membahas tentang padi, yaitu UU Nomor 19 Tahun 2013. UU ini membahas tentang perlindungan dan pemberdayaan padi, dengan garis besar menjelaskan bahwa negara secara khusus diharuskan untuk memenuhi hak dan kewajiban warga, terlebih lagi petani secara terencana, terarah, dan berkelanjutan. Penelitian ini penting dibaca untuk mengetahui kemampuan provinsi Jawa Timur, sebagai provinsi dengan kontribusi produksi beras terbesar di Indonesia, dalam mengentaskan kemiskinan di provinsinya menggunakan hasil produksi berasnya.

\section{Tinjauan Pustaka}

\section{Pengertian dan Indikator Kemiskinan}

Badan Perencanaan Pembangunan Nasional (2017) mendefinisikan kemiskinan sebagai suatu situasi yang serba kekurangan yang disebabkan oleh keadaan yang tidak dapat dihindari seseorang dengan kekuatan yang dimiliki (Kementerian PPN / Bappenas, 2017). Selain itu, World Bank mendefinisikan kemiskinan menggunakan ukuran daya beli seseorang, yaitu sebesar US \$1 atau US \$2 per kapita per hari. Badan Pusat Statistik (BPS) menggunakan garis kemiskinan dalam mengukur tingkat kemiskinan suatu individu, yaitu konsumsi minimum seseorang sebesar 2100 kalori per hari. Kemiskinan dapat dilihat dari pola waktu, dimana kemiskinan dibagi menjadi empat pola. Pola pertama disebut juga persistent poverty yaitu kemiskinan yang berasal dari orang tua. Pola ini terjadi di daerah tertentu yang cenderung tidak terdapatnya akses jalan. Pola kedua, yaitu cyclical poverty, merupakan kemiskinan yang terjadi akibat siklus ekonomi. Pola ketiga, seasonal poverty, terjadi kepada masyarakat yang mata pencaharian utamanya ditentukan oleh musim tertentu, seperti pertanian. Pola keempat, accidental poverty, yaitu kemiskinan yang terjadi akibat dampak dari regulasi yang mempengaruhi kesejahteraan masyarakat (Nurwati, 2008). BPS tahun 2003 menyatakan bahwa terdapat lima indikator dari Indeks Kemiskinan Manusia, yaitu (1) Tingkat persentase penduduk yang meninggal sebelum 40 tahun, (2) Tingkat persentase penduduk yang tidak memiliki akses air bersih, (2) Persentase penduduk yang mengidap buta huruf, (4) Persentase balita yang kekurangan gizi, (5) Persentase penduduk yang berjarak lebih dari 5 kilometer ke fasilitas kebersihan.

\section{Luas Panen di Jawa Timur}

BPS mendefinisikan luas panen sebagai hasil yang dipungut dari luasan tanaman ketika telah cukup umur. Agregasi antara luas panen padi sawah dan luas panen padi ladang menghasilkan luas panen padi (Damanik, 2016). Perkalian antara luas lahan dan intensitas tanam merupakan luas panen. Luas panen dapat dijadikan suatu indikator untuk melihat tingkat produksi yang dihasilkan, hal ini dikarenakan tingkat produksi beras turut dipengaruhi oleh luas panen padi (Gunawan, 2017). Faktor yang paling mempengaruhi jumlah produsi padi adalah luas panen (Ishaq, Rumiati, \& Permatasari, 2017). Vadimicum (dalam Triyanto, 2006) menyatakan bahwa luas panen 
meningkatkan kesejahteraan petani padi. Luas panen di Jawa Timur semakin besar, namun luas lahan sawah semakin menurun, hal ini dikarenakan dominannya intensitas panen dalam perkembangan luas panen (Hasan, 2010). Luas panen di Jawa Timur juga dapat menurun karena disebabkan alih fungsi lahan pertanian menjadi lahan nonpertanian, hal ini disebabkan pula oleh peningkatan jumlah penduduk setiap tahun di Jawa Timur, yang menyebabkan peningkatan pada permintaan lahan perumahan, infrastruktur, industri, dan lain sebagainya.

\section{Produktvitas Pertanian}

Produktivitas usaha tani merupakan salah satu indikator untuk meningkatkan produksi pertanian, sehingga diharapkan dapat menurunkan jumlah masyarakat yang tergolong miskin. Tingkat diterapkannya suatu teknologi pertanian dapat mencerminkan tingkat produktivitas pertanian per satuan (Gunawan, 2017). Peningkatan produktivitas pertanian yang dikaitkan dengan agroindustri dapat meningkatkan pertumbuhan sektor pertanian secara vertikal (Hasan, 2010). Maka dari itu, dibutuhkanlah peningkatan produktivitas. Ketahanan pangan dan lahan merupakan faktor penting yang dapat meningkatkan produktivitas pertanian (Cohen et al., 2003). Evenson dan Pray (1991) menyatakan bahwa pertumbuhan sektor pertanian dan produktivitas dipengaruhi oleh faktor infrastruktur, dimana salah satu infrastruktur tersebut adalah irigasi (Evenson \& Pray, 1991). Produksi pertanian perlu ditingkatkan untuk memenuhi permintaan dari masyarakat, dimana salah satu faktor yang dapat meningkatkannya adalah dengan meningkatkan produktivitas usaha tani padi (Setyawati \& Wibowo, 2019).

\section{Konsumsi Beras di Jawa Timur}

Badan Pusat Statistik (BPS) memperhitungkan penduduk miskin menggunakan suatu konsep menggunakan kemampuan seseorang dalam memenuhi kebutuhan dasarnya (basic needs approach). Menurut BPS, pendekatan ini memandang kemiskinan sebagai suatu ketidakmampuan dalam sisi perekonomian dalam memenuhi kebutuhan dasar makanan serta bukan makanan yang turut diukur melalui sisi pengeluaran seseorang. BPS juga turut menjelaskan bahwa Penduduk Miskin merupakan penduduk yang rata-rata pengeluaran perkapita perbulannya berada di bawah garis kemiskinan. Perubahan harga beras akan mempengaruhi daya beli beras masyarakat yang tergolong miskin (Arifin, 2006). Peningkatan penduduk juga turut meningkatkan kebutuhan konsumsi beras. Berdasarkan data Badan Pusat Statistik, Jawa Timur selalu mengalami peningkatan penduduk. Hal ini dapat disimpulkan bahwa tingkat konsumsi beras di Jawa Timur juga turut meningkat. Keadaan surplus beras merupakan keadaan ketika ketersediaan beras lebih besar dari konsumsinya, sedangkan defisit beras adalah ketika ketersediaan lebih sedikit dari tingkat konsumsinya (Santoso, 2015). Maka dari itu, agar dapat menghindari terjadinya ketimpangan antara banyaknya populasi dengan ketersediaan beras, dibutuhkanlah perencanaan atas kebutuhan konsumsi beras (Popi, 2013). Penelitian oleh Sayogyo pada tahun 1971 menggunakan variabel tingkat konsumsi beras di daerah pedesaan dan perkotaan sebagai indikator kemiskinan (dalam Cahyat, 2004). Nuryanti (2005) menyatakan bahwa jumlah penduduk yang meningkat dalam jangka panjang sebesar $1 \%$ dapat meningkatkan permintaan beras sebesar $0,82 \%$.

\section{METODE}

Penelitian ini menggunakan data panel. Data panel merupakan kombinasi antara data cross section dan data time series. Dimana data cross section terdiri dari satu entitas, sedangkan time series adalah data satu entitas dengan dimensi waktu yang panjang (Iqbal, 2015). Analisis regresi data panel merupakan suatu analisis regresi dengan menggunakan data panel yang bertujuan untuk melihat hubungan antara satu variabel dependen dengan satu atau beberapa variabel independen (Jaya \& Sunengsih, 2009). Hal ini dikarenakan data panel dapat memberikan hasil analisis yang bersifat Best Linear Unbiased Estimation (BLUE) jika seluruh asumsi Gauss Markov dapat terpenuhi (Jaya \& Sunengsih, 2009) . Sehingga bias yang mungkin terjadi dapat diminimalisir (Pangestika, 2015). Terdapat dua metode untuk melakukan estimasi data panel, yaitu Fixed Effect (FE), dan Random Effect (RE) (Santi, 2015). Selanjutnya, untuk menentukan metode terbaik untuk digunakan dalam analisis adalah dengan menggunakan uji hausman (Sakti, 2018).

Penelitian ini menggunakan analisis kualitatif dengan data sekunder yang didapatkan dari situs Badan Pusat Statistik (BPS) dan Kementerian Pertanian Republik Indonesia (KPRI) dengan data tingkat kabupaten kota pada tahun 2015 hingga 2017. Penulis menggunakan data panel dengan metode Fixed-Effect yang kemudian diolah menggunakan aplikasi STATA14. Objek yang menjadi fokus dalam analisis ini adalah jumlah penduduk miskin, luas panen, tingkat produktivitas petani, tingkat produksi padi, serta tingkat konsumsi masyarakat di Jawa Timur. Penelitian ini menggunakan satuan ribu jiwa untuk penduduk miskin, hektar (Ha) untuk luas panen, kwintal per hektar (Kw/Ha) untuk tingkat produktivitas, Ton untuk tingkat produksi, dan persen untuk tingkat konsumsi pangan masyarakat. Berikut merupakan model ekonometrika yang digunakan:

lpoverty $_{i t}=\beta_{0}+\beta_{1}$ Iproduktif $_{i t}+\beta_{2}$ lluas $_{i t}+\beta_{3}$ konsumsi $_{i t}+u_{i t}$, 
Diana Rizky Safitri dan Estro Dariatno Sihaloho, Lumbung Padi Indonesia dan Kemiskinan: Studi Kasus Kabupaten Kota di Jawa Timur

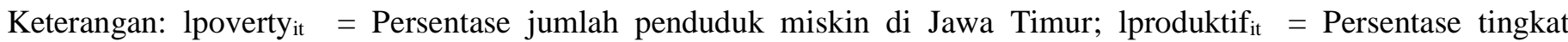
produksi beras di Kabupaten Kota Jawa Timur; lluas ${ }_{\mathrm{it}}=$ Persentase tingkat produksi beras di Kabupaten Kota Jawa Timur; konsumsi $_{\text {it }}=$ Persentase tingkat konsumsi di Kabupaten Kota Jawa Timur; $\mathrm{u}_{\mathrm{it}}=$ Error

\section{HASIL}

Jumlah observasi, rata-rata, standar deviasi, nilai minum, dan nilai maksimum dari masing-masing variabel yang digunakan dalam melakukan analisis regresi, dengan data yang berasal dari BPS Kabupaten Kota Jawa Timur Tahun 2014 hingga 2017 dengan jumlah observasi sebanyak 152 observasi:

Tabel 1

Tabel Deskripsi Statistik

\begin{tabular}{|c|c|c|c|c|c|}
\hline Variabel & Obs & Mean & SD & Minimum & Maximum \\
\hline lpoverty & 152 & 4.473 & 1.036 & 1.980 & 5.683 \\
\hline lproduktif & 152 & 1.766 & 0.109 & 1.416 & 2.068 \\
\hline lluas & 152 & 10.239 & 1.647 & 6.111 & 12.021 \\
\hline lkonsumsi & 152 & 3.910 & 0.131 & 3.519 & 4.173 \\
\hline
\end{tabular}

Sumber: Badan Pusat Statistik Jawa Timur, diolah

Berdasarkan Uji Hausman, terdapat dua model yang dapat digunakan, yaitu Random Effect dan Fixed Effect. Hipotesis yang digunakan dalam analisis ini adalah:

Ho: Perbedaan pada koefisien tidak sistematis, yang berarti koefisien dari dua regresi tidak berbeda secara signifikan. Ha: Perbedaan pada koefisien sistematis, yang berarti koefisien dari dua regresi berbeda secara signifikan.

Kriteria yang digunakan adalah sebagai berikut:

Jika prob $<\alpha$, Ho ditolak

Jika prob $>\alpha$, Ho tidak dapat ditolak

Tabel 2

Hasil Uji Hausman

\begin{tabular}{lll}
\hline Chi2(3) & $=$ & 935.41 \\
\hline Prob $>$ Chi2 & $=$ & 0.0000 \\
\hline Sumber: data & &
\end{tabular}

Sumber: data olahan

Uji Hausman menunjukan bahwa nilai dari p-value lebih kecil dari tingkat signifikansi, dimana $p$-value $<\alpha$, sehingga dapat diartikan bahwa Ho ditolak. Maka dari itu, metode terbaik yang digunakan dalam analisis ini adalah metode fixed-effect.

Tabel 3

Hasil Regresi menggunakan STATA14

\begin{tabular}{|c|c|}
\hline Variable & Fixed Effect \\
\hline lproduktif & $\begin{array}{l}-0.110^{*} \\
(0.0644)\end{array}$ \\
\hline lluas & $\begin{array}{l}-0.0893 * * \\
(0.0393)\end{array}$ \\
\hline lkonsumsi & $\begin{array}{l}-0.133 * * \\
(0.00144)\end{array}$ \\
\hline Constant & $\begin{array}{l}6.103 * * * \\
(0.560)\end{array}$ \\
\hline Observations & 152 \\
\hline Number of numwilayah & 38 \\
\hline R-squared & 0.071 \\
\hline
\end{tabular}

Standard errors in parentheses $* * * \mathrm{p}<0.01, * * \mathrm{p}<0.05, * \mathrm{p}<0.1$

Sumber: data olahan

Tabel 3 menunjukan bahwa semua variabel independen mempengaruhi variabel dependen secara signifikan. Hasil regresi menunjukan bahwa tingkat persentase produktivitas, persentase luas lahan, dan konsumsi memiliki pengaruh negatif terhadap jumlah penduduk miskin di Jawa Timur tahun 2014 sampai 2017. Nilai konstanta pada model menunjukan angka 6.103, sehingga dapat dijelaskan bahwa ketika tidak dipengaruhi oleh variabel lain, nilai persentase kemiskinan menurun sebesar 6.103 persen. Hasil regresi menunjukan bahwa nilai persentase produktivitas petani di Jawa Timur pada tahun 2014 - 2017 memiliki korelasi negatif dan signifikan terhadap tingkat kemiskinan di 
Jawa Timur sebesar 0.110 dengan tingkat signifikansi sebesar 1\%. Hal ini dapat dinyatakan bahwa peningkatan 1 unit persentase produktivitas akan menurunkan tingkat kemiskinan sebesar 0.110 , ceteris paribus. Hal ini sesuai dengan penelitian Hermawan (2015) dan Effendy (2017) yang menyatakan bahwa semakin produktif petani akan menurunkan tingkat kemiskinan.

Grafik 2

Tingkat Luas Lahan dan Kemiskinan di Jawa Timur Tahun 2012 - 2017

\begin{tabular}{|l|l|l|l|}
\hline 2350000 & & & \\
2 \\
2300000
\end{tabular}

Sumber: Badan Pusat Statistik, 2018

Grafik 2 menunjukan terdapat hubungan negatif antara variabel luas lahan dengan tingkat kemiskinan. Hasil regresi menunjukan bahwa nilai persentase luas lahan pertanian di Jawa Timur pada tahun 2014 - 2017 memiliki korelasi negatif dan signifikan terhadap tingkat kemiskinan di Jawa Timur sebesar 0.0893 dengan tingkat signifikansi sebesar 5\%. Hal ini dapat dinyatakan bahwa peningkatan 1 unit persentase luas lahan akan menurunkan tingkat kemiskinan sebesar 0.0893, ceteris paribus. Hal tersebut sesuai dengan penelitian sebelumnya oleh Arifin (2006) dan Badan Pusat Statistik (2010) yang menyatakan bahwa peningkatan pada luas lahan akan menurunkan tingkat kemiskinan. Selanjutnya, variabel persentase konsumsi memiliki korelasi negatif dengan persentase kemiskinan di Jawa Timur dengan koefisien 0.133. Sehingga dapat diartikan bahwa peningkatan konsumsi sebesar 5\% dapat menurunkan persentase kemiskinan sebesar 0.133 ceteris paribus. Hal ini sesuai dengan penelitian sebelumnya oleh Rini \& Sugiharti, (2016) dan Wahyudi \& Rejekingsih (2015) yang menyatakan bahwa semakin tinggi konsumsi seseorang, semakin jauh orang tersebut dari garis kemiskinan.

\section{SIMPULAN}

Penelitian ini menunjukan adanya korelasi antara sektor pertanian dengan tingkat kemiskinan di kabupaten kota Jawa Timur. Penelitian ini menggunakan data panel dengan metode Fixed Effect yang menunjukan bahwa persentase produktivitas, luas lahan, dan konsumsi masyarakat di Kabupaten Kota Jawa Timur memiliki pengaruh negatif dan signifikan terhadap persentase kemiskinan di kabupaten kota di Jawa Timur. Penelitian ini dapat digunakan sebagai rekomendasi untuk mengurangi tingkat kemiskinan di kabupaten kota Jawa Timur melalui sektor ertanian. Peningkatan pada luas lahan, produktivitas petani, serta konsumsi masyarakat dapat menurunkan tingkat kemiskinan di kabupaten kota Jawa Timur. Penurunan persentase kemiskinan menunjukan bahwa kabupaten kota Jawa Timur telah berhasil mengentaskan kemiskinannya dengan sektor pertaniannya.

\section{DAFTAR PUSTAKA}

Arifin, B. (2006). Pemikiran untuk Mengeluarkan Petani dari Kemiskinan. Jurnal Pangan, (46). https://doi.org/10.33964/jp.v15i1.278

Cahyat, A. (2004). Bagaimana Kemiskinan Diukur? Center for International Forestry Research, 1-8.

Cohen, C., Crosson, P., Eynard, A., Heisey, P., Jones, C., Malcolm, S., ... Weber, I. J. (2003). Acknowledgments. (823).

Damanik, S. (2016). Keterkaitan Ketahanan Pangan dengan Kemiskinan Berdasarkan Implementasi Kebijakan Penanggulangan Kemiskinan di Indonesia. Economics Development Analysis Journal, 5(1), 38-47. 
Diana Rizky Safitri dan Estro Dariatno Sihaloho, Lumbung Padi Indonesia dan Kemiskinan: Studi Kasus Kabupaten Kota di Jawa Timur

https://doi.org/https://doi.org/10.15294/edaj.v5i1.22002

Effendy, R. S. (2017). Peranan Pendidikan dan Produktivitas Sektor Pertanian terhadap Penurunan Tingkat Kemiskinan di Jawa Tengah. Media Ekonomi Dan Manajemen, 32(2), 108-118. https://doi.org/10.24856/mem.v32i2.511

Evenson, R. E., \& Pray, C. E. (1991). Research and Productivity in Asian Agriculture. Ithaca: Cornell University Press, 1049-1051.

Gunawan, C. I. (2017). Pengaruh Luas Panen, Produktivitas, Konsumsi Beras, dan Nilai Tukar Petani terhadap Ketahanan Pangan di Kabupaten Brebes. Unviersitas Negeri Semarang.

Hasan, F. (2010). Peran luas panen dan produktivitas terhadap pertumbuhan produksi tanaman pangan di jawa timur. EMBRYO, 7(1), 3-8.

Hermawan, I. (2015). Analisis Eksistensi Sektor Pertanian terhadap Pengurangan Kemiskinan di Pedesaan dan Perkotaan. MIMBAR Jurnal Sosial Dan Pembangunan, 28(2), 135-144. https://doi.org/https://doi.org/10.29313/mimbar.v28i2.348

Iqbal, M. (2015). Operasionalisasi Regresi Data Panel (Vol. 4). Retrieved from https://dosen.perbanas.id

Ishaq, M., Rumiati, A. T., \& Permatasari, O. (2017). Analisis Faktor-Faktor yang Mempengaruhi Produksi Padi di Provinsi Jawa Timur Menggunakan Regresi Semiparametrik Spline. Jurnal Sains Dan Seni ITS, 6(1), 7.

Jaya, I. G. N. M., \& Sunengsih, N. (2009). Kajian Analisis Regresi dengan Data Panel. Prosiding Seminar Nasional Penelitian, Pendidikan Dan Penerapan MIPA, 51-58. Retrieved from http://eprints.uny.ac.id/id/eprint/12187

Kementerian PPN / Bappenas. (2017). Membedah Angka Kemiskinan dan Kesenjangan: Rilis Data Terkini BPS. Retrieved from https://www.bappenas.go.id

Na'im, A. (1999). Nilai Informasi Ketepatan Waktu Penyampaian Laporan Keuangan: Analisis Empirik Regulasi Informasi di Indonesia. Jurnal Ekonomi Dan Bisnis Indonesia, 14. Retrieved from https://jurnal.ugm.ac.id/jieb/article/view/39445

Nurwati, N. (2008). Kemiskinan: Model Pengukuran, Permasalahan dan Alternatif Kebijakan. Jurnal Kependudukan Padjadjaran, 10(1), 1-11.

Pangestika, S. (2015). Analisis Estimasi Model Regresi Data Panel dengan Pendekatan Common Effect Model (CEM), Fixed Effect Model (FEM), dan Random Effect Model (REM). Universitas Negeri Semarang.

Popi, R. (2013). Model Optimasi Surplus Beras Untuk Menentukan Tingkat Ketahanan Pangan Nasional. Seminar Nasional FMIPA UT, 62-75. Retrieved from http://repository.ut.ac.id/2483/

Rini, A. S., \& Sugiharti, L. (2016). Faktor-Faktor Penentu Kemiskinan di Indonesia: Analisis Rumah Tangga. Jurnal Ilmu Ekonomi Terapan, 1(2), 17-33. https://doi.org/http://dx.doi.org/10.20473/jiet.v1i2.3252

Rum, I. A., \& Sihaloho, E. D. (2017). Menjawab Anomali Harga Komoditas Beras berdasarkan Tingkat Kerentanan Perubahan Iklim di Indonesia. ISEI Economic Review, I(2), 42-45. https://doi.org/https://doi.org/10.36217/ier.v1i2.26

Sakti, I. (2018). Analisis Regresi Data Panel Menggunakan EViews. Jakarta: Universitas Esa Unggul.

Santi, F. (2015). Model Regresi Panel Data dan Aplikasi Eviews.

Santoso, A. B. (2015). Pengaruh Luas Lahan dan Pupuk Bersubsidi Terhadap Produksi Padi Nasional (Effect of Land Use and Subsidized Fertilizer for National Rice Production). Jurnal Ilmu Pertanian Indonesia, 20(3), 208-212. https://doi.org/10.18343/jipi.20.3.208

Sawit, M. H. (2006). Indonesia dalam Tatanan Perubahan Perdagangan Beras Dunia. Jurnal Pangan, (47), 16-23. https://doi.org/10.33964/jp.v15i2.291

Setyawati, I. K., \& Wibowo, R. (2019). Efisiensi Teknis Produksi Usahatani Tebu Plant Cane dan Tebu Ratoon Cane (Studi Kasus di PT. Perkebunan Nusantara). Journal of Social and Agriculture Economics, 12(1), 80-88. https://doi.org/https://doi.org/10.19184/jsep.v12i1.9950

Triyanto, J. (2006). Analisis Produksi Padi di Jawa Tengah. Universitas Diponegoro.

Wahyudi, D., \& Rejekingsih, T. W. (2015). ANALISIS KEMISKINAN DI JAWA TENGAH. 2, 1-15.

World Bank. (2018). Mengurangi Kemiskinan. Retrieved from https://siteresources.worldbank.org 